\title{
INCREASING THE SOCIO-CULTURAL RELEVANCE OF SCIENCE EDUCATION FOR SUSTAINABLE DEVELOPMENT
}

\author{
Gilbert O. M. Onwu ${ }^{1}$ and William C. Kyle, Jr. ${ }^{2}$ \\ ${ }^{1}$ University of Pretoria, South Africa \\ ${ }^{2}$ University of Missouri - St. Louis, USA \\ 1'gilbert.onwu@up.ac.za; ${ }^{2}$ bill_kyle@umsl.edu
}

\begin{abstract}
Socio-scientific issues should be considered in the course of students' formal education in science as one of the ways in which science education ought to be connected to the goals of sustainable development. Approaches to education in science still perpetuate a way of thinking that is incommensurable with preparing learners to develop the understandings and skills requisite for active participation in an uncertain and complex world. In addition, uptake of science is declining worldwide, poverty is deepening, and environmental degradation is worsening. We argue herein that finding ways to link science education to issues of sustainable development could provide the basis for making science more relevant to learners, as well as better prepare learners for active participation in society. We raise the question: How can science education be more relevant, thereby enabling learners to deal with complex everyday issues and participate in decision-making oriented toward the goals of sustainable development? Drawing on experiences of interdisciplinary dialogue, we illustrate how reformulating the agenda in science education, such that it is oriented toward sustainable development, offers the basis for relevant teaching and learning vis-à-vis the engagement of learners in active learning processes.
\end{abstract}

Key words: socio-scientific issues, sustainable development, relevant science education

\section{Interest in Socio-Scientific Issues}

The global population presently uses resources at a rate $40 \%$ faster than the planet can regenerate in a calendar year. As recently as around 1980, "the global community consumed resources and produced carbon dioxide at a rate consistent with what the planet could produce and reabsorb" (Global Footprint Network, What is Overshoot? section, 94). In essence, in the course of about 30 years we have seen a shift from sustainable living globally to a situation where we increasingly overspend the ecological resources at a faster and faster rate (sustainable living globally in 1980 did not imply equitable consumption of resources as some nations used a lot less and some used a lot more; this is certainly true today as well). In 2009, Earth Overshoot Day was reached on September $25^{\text {th }}$. If we continue with a business as usual lifestyle 
and do not begin to make significant changes, then around the time children born in 2009 graduate from college the Earth Overshoot Day will be July $1^{\text {st }}$. What this means is that in the early 2030s it would take two years for the Earth to regenerate what is used in one year. Reaching this level of ecological deficit spending may be physically impossible (Ewing, Goldfinger, Wackernagel, Stechbart, Rizk, Reed \& Kitzes, 2008).

Clearly over the course of the next 20 years, between now and the timeframe we have identified in the early 2030s, a different kind of community of practice in science classrooms is going to have to emerge. Just as a business as usual mindset, "which is destroying the economy's eco-supports and setting the stage for dangerous climate change, is no longer a viable option" (Brown, 2008, xii) within society-at-large; a business as usual mindset with respect to science education can no longer be tolerated. We concur with Sadler (2009) when he calls "for the development of communities of practice in science classrooms that prioritize socio-scientific Discourses and development of identities reflective of engaged citizenship" (p. 12). Such a transformation is essential for learners to engage with science in meaningful and relevant ways. Sadler further states:

An important objective for science education ought to be for learners to come to identify themselves as willing and able to engage in socio-scientific Discourses. As such, learners come to position themselves as active contributors to society with competencies and willingness to employ scientific ideas and processes, understandings about science and social knowledge (e.g., ideas about economic and ethical influences) to issues and problems that affect their lives. The goal is for learners to develop a sense of having something to say about these issues and to see themselves as legitimate participants in social dialogues. (Sadler, 2009, pp. 12 - 13)

Wackernagel (2008) asserts "many opinion leaders are trapped in the misconception that advancing sustainability is detrimental to the economy, an expense that will only be affordable at some later date. Unfortunately, later is now, and the consequences of putting off change until later is that countries, and humanity as a whole, will be unprepared for the challenge of living within the limits of our natural resources" ( $p$. 1). He envisions those who prepare for living in a resource-constrained world will fare far better than those who do not. Moreover, he contends in an age of growing resource scarcity, the wealth of nations will be defined in terms of ecological assets. Preparing for this new economic reality will take time, making it urgent to begin as quickly as possible. Strategies will need to be simultaneously put in place to better manage and protect ecological reserves, while minimizing or reducing a nation's demand on ecosystem services.

The world is facing almost insurmountable challenges. These challenges transcend national boundaries. The Millennium Project has identified 15 global challenges that 
"provide a framework to assess the global and local prospects for humanity" (Glenn, Gordon, \& Florescu, 2009, p. 10; refer to Figure 1). Our ability to provide life's essentials: food, water, shelter and energy, for an ever expanding human population and within the carrying capacity of supporting ecosystems, will require major advances in science and technology and a scientifically literate citizenry.

Glenn, Gordon, \& Florescu (2011) assert that "the world has the resources to address its challenges. What is not clear is whether the world will make good decisions fast enough and on the scale necessary to really address the global challenges. Hence, the world is a race between implementing ever-increasing ways to improve the human condition and the seemingly ever-increasing complexity and scale of global problems" (p. 2).

Given the urgent need for humanity to generate and implement effective responses to current challenges, there is recognition among governments that fundamental reordering of global priorities is needed in order to implement the goals of sustainable development. This recognition was first enshrined in the Declaration of the Earth Summit in Rio de Janeiro in 1992, which placed emphasis on strategies for preventing environmental degradation and for establishing a basis for achieving sustainable balance between nature and the human economy into the twenty-first century. Ten years later, in 2002, when the World Summit on Sustainable Development (WSSD) convened in Johannesburg, it was hardly a point of dispute that not much progress had been made at the level of local communities for most global environmental issues (United Nations, 2002). With poverty deepening and becoming more widespread, and environmental degradation of essential ecosystems worsening, we can question whether the subsequent actions and recommendations of the World Summit have been able to contribute in meaningful and realistic ways to achieving sustainable development. We believe it is important for science educators to ask: What are the implications of WSSD for science education?

In 2009, the International Council of Associations for Science Education (ICASE) sponsored a conference with the theme "Meeting Challenges to Sustainable Development in Africa through Science and Technology Education." The conference was intended to provoke lively debate and discussion regarding the ways in which science education may be connected to issues of sustainable development. In striving for the promotion of science education for sustainable development, any such debate should include examples which highlight the value of science learning relevant to the needs of a changing society and to the needs of both boys and girls as future citizens, whatever their future career aspirations may be. Such examples would include science teaching emphasizing student learning of - and assessment strategies associated with - skills and competencies promoting problem-solving and socioscientific decision-making. In essence, the question that arises is simply this: In what ways should science education be more intrinsically linked to issues of sustainable development? Herein we argue that answers to this question ought to provide a 
veritable means of making science education more relevant to the needs of learners and society. We offer the assertion that the aims of science education are intrinsically linked to one's conception of scientific literacy. We concur with Roberts (2007) when he notes the visions of scientific literacy materialize from the contexts in which science subject matter is taught. He refers to these contexts as curriculum emphases (Roberts 1982, 1988).

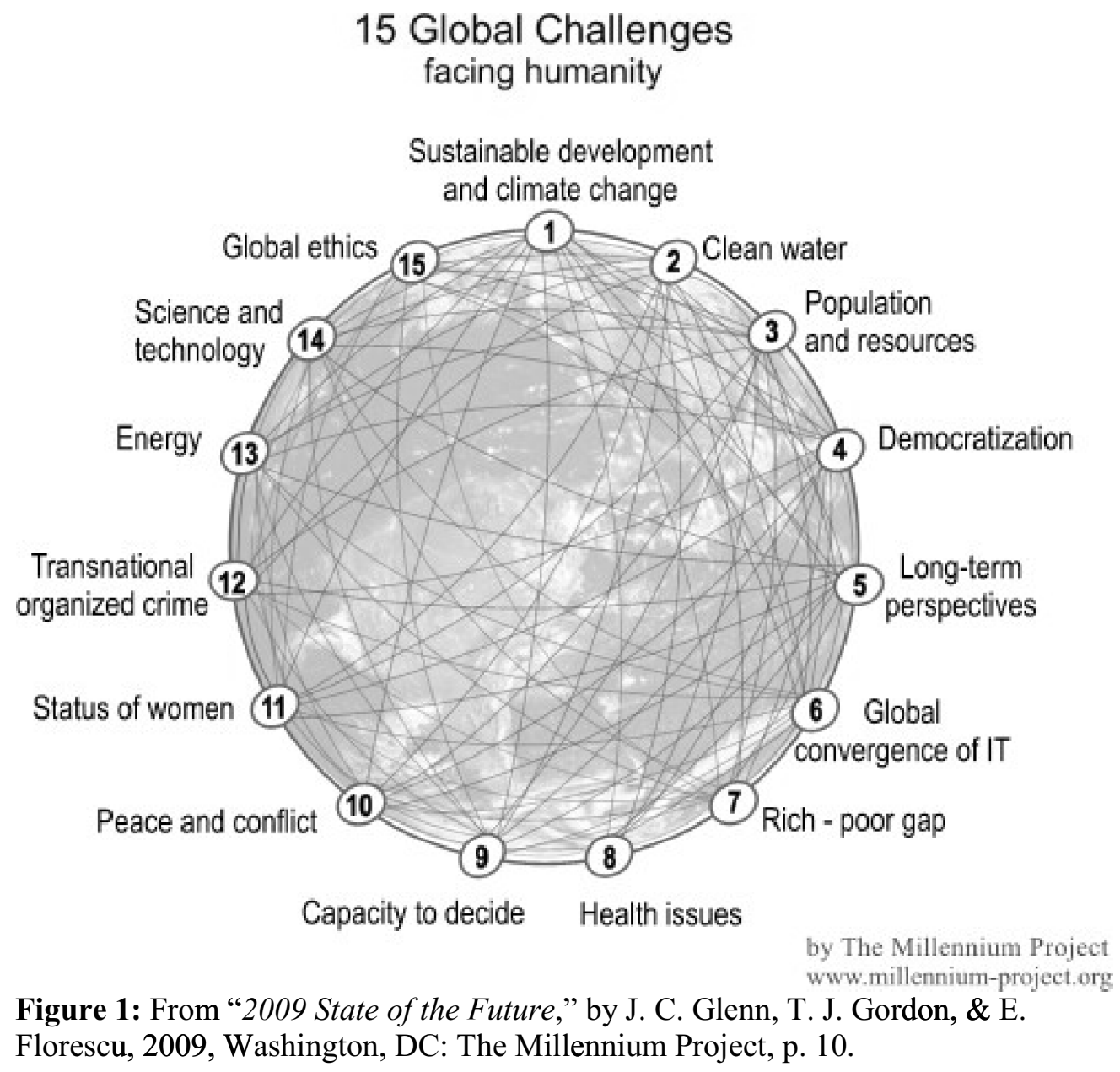

Roberts (2007) indicates there seem to be two visions of scientific literacy representing the extremes on a continuum, which he refers to as Vision I and Vision II. For Roberts, "a vision is a much broader analytical category than, say, a definition" (p. 730). Vision I is "rooted in the products and processes of science" (p. 730). Advocates of Vision II, the perspective from which we (the authors) emanate, 
stress the importance of starting "with situations, then reaching into science to find what is relevant" (p. 730). Roberts elaborates further by stating:

What is important to recognize is that advocates of Vision II stress that all students in democratic societies - regardless of their career plans - need to develop SL (scientific literacy) that is appropriate to situations other than conducting scientific inquiry. Thus, for example, an understanding of scientific inquiry is not only important for potential scientists, in Vision II thinking. It is a vital component of a citizen's ability to keep scientific perspective in balance with others. Thus, students need classroom experience with situations in which different perspectives are deliberately brought to bear in socio-scientific issues. (2007, p. 771).

Traditionally, scientific literacy has been framed in terms of past knowledge. Such a perspective fails to capture dynamic aspects of the emergence / disappearance of new literacies (Roth, 2007). We agree with van Eijck's (2007) notion of scientific literacy as an emergent feature of collective praxis. This notion is "grounded in a conception of knowledge as a collective and distributed cognitive entity" (p. 255). He notes that "grounding the concept of scientific literacy in a cultural-historical perspective allows the articulation of what being scientifically literate means" (p. 256).

We are in agreement with many other science educators (e.g., Davies, 2004; Hodson, 2003; Roth \& Lee, 2004; Sadler, 2009), when we take the position that it is problematic for science education to be primarily aimed at promoting future success in the culture of schooling without links beyond school science to communities, society, self-and social empowerment, and / or social transformation. Sadler (2009) suggests science education should seek to accomplish more than just helping students to develop Discourses and identities enabling them to succeed in higher levels of school science; such an orientation falls far short of the aims that science education ought to assume. He states:

Science as it is practiced in the lived experiences of engaged citizens can serve as the basis for developing a different kind of community of practice in science classrooms. The underlying premise is that we position science classrooms as contexts for students and teachers to actively explore issues and problems with two necessary elements: (1) conceptual and/or procedural connections to science; and (2) social significance, preferably as judged by the community participants themselves. This class of issues and problems has been termed socio-scientific issues (SSI). (Sadler, 2009, p. 11)

Socio-scientific issues often frame social transformation concerns of many African countries. These include adequate health care, hunger, malnutrition or undernourishment, lack of safe drinking water, poverty and un/under-employment, subsistence agriculture in small holdings, soil erosion, HIVAIDS, deforestation, 
reduction of biodiversity, disease, and many other related social concerns. For a third of the world's population, the only source of fuel for cooking is firewood. The unchecked exploitation of the forests and vegetation, particularly in the developing countries of Africa, has had catastrophic impact on the natural environment and ecosystems. Such human conditions that pertain to science education have been well documented and corroborated in various UN and World Bank publications (see, for example, Finger \& Schuler, 2004; UNICEF, 2003; World Bank, 2003, 2004a, 2004b, 2004c). These human conditions however, offer stark and contrasting images of the ways in which people in developed and developing countries are linked to the environment (Kyle, 2006). For instance, the more industrialized countries have long experienced the uneasy relationship between environmental protection and economic development. For the developing countries, it was only in the 1980s that it dawned on society that the lack of development (i.e., poverty) is just as effective in damaging the environment as is development (Ratcliffe \& Grace, 2003). The fact remains, whether human societies appear to be closely tied to the environment or not, their impact upon the environment is crucial for their continued survival and success (Kyle, 2006).

In the coming years, one of the most pressing challenges confronting the developing countries of Africa is how to address in sustainable ways environmental and social issues central to sustainable development. How can African countries achieve the goals of sustainable development - one that meets human needs, while protecting and restoring the natural environment - when many African countries are faced with problems that appear too numerous and / or virtually impossible to overcome? Part of the answer, perhaps, lies in Annan's (2002) suggestion in strengthening partnerships among governments and non-governmental organisations, including others in a position to contribute, such as the academic and scientific communities. Besides needing strong partnerships, what is clearly required is an active and participatory citizenry. Right now, the challenges facing effective strategies for sustainable development in Africa cannot be handled by government alone. As science educators, we must begin to find ways to take action that would seek to counteract those debilitating human conditions that persist for a significant percentage of the African population, and which prevent the achievement of the world's goals for education. This intervention would make it imperative for Africa's education system to embrace the principles of sustainable development, both for students who attend formal education as well as for the millions of students who never enter the place called school and yet are members of society. Both formal and informal science education has much to offer in helping to develop and strengthen student and citizen life-skills in areas that would help society progress on implementing pathways to new and more sustainable ways of living in harmony with Planet Earth.

\section{Relevance of Science Education}

In recent years, one of the most discernible trends in science education worldwide is the declining number of students going into science and science-related careers. 
There has been - and continues to be - widespread concern in a number of countries over the uptake of science. For example, in South Africa a demonstrably low percentage of all post-secondary education degrees are in mathematics, science or engineering. South Africa's ratio of scientists and engineers to the population stands at 3.3 per 1000 compared with 21.5 per 1000 and 71.1 per 1000 in the US and Japan respectively (National Research Foundation Report, 2005). The situation is worse in most other African countries as they struggle to address a variety of challenges with their educational systems. Collectively these challenges are regarded as a crisis of relevance. From a science education perspective, one can regard this as a crisis as a failure to meet the needs of both students and society in a rapidly changing environment.

Science remains one of the most important subjects in the school curriculum. But the science education curriculum has failed to excite students for at least two reasons. First, it is frequently taught as rote memorization of complex facts and abstract or meaningless data, which in a sense is antithetical to the visceral-driven way we live and interact with our world. Secondly, science educators have failed in their social responsibility to provide students and the general public with an understanding of science as it is today, especially in terms of its history, its powers and limitations (Kyle, 2006; Ziman, 2000). Students are not provided opportunities to 'see' the relevance of studying science at school and beyond. The teaching of science has gradually become isolated from society. Various studies have established that learners do not perceive the study of science as being relevant to their lives (Anderson 2006; Jenkins and Pell, 2006; Schayegh, 2007; Schreiner \& Sjøberg, 2004). This lack of appreciation of the relevance of science could be attributed to the way science is taught. For instance, the ideas and major conclusions of science play important roles in many of the decisions that humans have to take with regard to contested socio-scientific issues. One such topical issue is the treaty on the ban of nuclear proliferation by signatory members, which has in recent times generated a lot of debate about its implication for its development for peaceful purposes. But given the way science is now taught, it would hardly be surprising if any such issues are presented in ways that include moral issues (Bowers, 2001; Kyle 2006). Bowers (2001) has questioned the wisdom of treating education in the sciences as entirely separate from moral issues. Science educators engaged in the STS movement of the 1980s would certainly concur. Solomon and Aikenhead (1994) capture the commitment of STS curricular innovations to social responsibility, moral responsibility, empowerment, critical thinking, problem solving and decision making. Similarly, Cheek (1992) presented a model for STS curriculum development in science, social studies, and technology education, along with a constructivist research agenda for STS education. The recommendations for a research agenda were comprehensive and insightful, yet the community of science educators engaged in STS education never really advanced the agenda. Cheek (1992) warned science educators that efforts to promote scientific or technological literacy must be more than slogans. And, his desire was for such efforts to translate into worthwhile 
research and development strategies that could move the entire debate forward in more promising directions. Regrettably, many curriculum resources were developed to support STS approaches, yet macro-structures such as regulations concerning the use of high-stakes tests can leave science teachers with feelings of being disempowered and having to teach towards the test (Tobin, 2009).

Far too little attention is paid to the personal rewards of science. Caldin (1949) explored this topic and came to the conclusion that the place of science in society is too often considered in the narrow setting of economic welfare alone, so the potential contribution of science to the growth of the mind is underestimated. To Caldin's observation, we will also add the neglect of science's potentially beneficial effect on personal development, especially its links with the kind of meaningful and transformative education (Barton \& Osborne, 2001; Heater, 1999; Roth \& Desautels, 2002) that is imperative for sustainable development. Science courses from elementary through undergraduate studies continue to be structured and taught from the perspectives of an uncritical acceptance of logical positivism, and to a large extent as a mastery of abstract concepts and principles, rarely explicitly linked to real life experiences (Kyle, 2006; Onwu, 2000). The link between science education and "real world" experiences is almost always tenuous in the minds of present day science learners. The failure of science educators to develop curricular connection between science and the day-to-day lived experiences of learners is likely to obscure and diminish the relevance of science in their lives (Onwu, 2000).

Students' dwindling interest, low motivation to learn, and poor performance in science can all be attributed to the lack of recognizable relevance of science teaching by learners. Alienation of learners from the discipline of science may be seen - at least in part - as a failure of the curriculum and the teaching-learning process (Stears, Malcolm, \& Kowlas, 2003). Science education ought to move progressively towards a real world, context-based approach to the teaching and learning of science at all levels of the school curriculum (Holbrook, 2009).

In an edited collection of articles originating from a symposium on "International Perspectives on Environmental Learning, Participation and Agency" at the 2007 Annual Meeting of AERA, Stevenson and Dillon (2010) emphasize the importance of engaging learners as active agents. Meaningful learning about and informed action on environmental issues requires critical inquiry and reflection, as well as imagination to generate possibilities for creating more sustainable socio-ecological practices, and action to ameliorate current environmental concerns. The various chapters in the volume highlight the challenges and complexity of engaging youth and adults in meaningful learning. 


\section{The Meaning of Relevant Science Education}

It is appropriate to try to establish a working definition of relevant science education, particularly in the context of promoting education for sustainable development. This is because notions or concepts of sustainable development are far reaching and have varying meanings / purposes in the minds of students, teachers, citizens, scientists, or politicians.

An example of a curriculum policy document that explicitly acknowledges the significance of discourses other than that of orthodox science is South Africa's national curriculum policy for natural sciences. It states that "The Natural Sciences Learning Area deals with the promotion of scientific literacy. It does this by:

- the development and use of science process skills in a variety of settings;

- the development and application of scientific knowledge and understanding; and

- the appreciation of the relationships and responsibilities between science, society, and the environment" (Department of Education, Pretoria, 2002, p. $4)$.

The document elaborates on each of these three aspects of scientific literacy, synthesizes their intended meaning in three broad learning outcomes, and provides an extended discussion of how the three components can be assessed. The third outcome, described as "challenging, with potential to broaden the curriculum and make it distinctively South African" (p. 10), is of special interest because it includes attention to relationships between science and traditional practices / technologies as these relate to traditional wisdom and knowledge systems. "One can assume that learners in the Natural Sciences Learning Area think in terms of more than one world-view. Several times a week they cross from the culture of home, over the border into the culture of science, and then back again. How does this fact influence their understanding of science and their progress in the Learning Area? Is it a hindrance to teaching or is it an opportunity for more meaningful learning and a curriculum which tries to understand both the culture of science and the cultures of home?" (p. 12).

In the context of schooling, relevance implies here the use of community or community-based resources and the incorporation of local issues and practices into the science curriculum (Holbrook, 2009). Thus, context or issues based learning is seen in the eyes of the student as something useful, worthwhile, meaningful and important. We believe relevant science education has much to offer in promoting intrinsic motivation in the student for self-involvement and self- and socialempowerment. 
Malcolm, Gopal, Keane, and Kyle (2009), in collaboration with two rural communities in South Africa, sought to investigate what the communities considered to be 'relevant science education.' The nature of the research question and the researchers' commitment to human rights and democracy rendered transformative action research an appropriate orientation for their inquiry. They found their initial open-ended approach was rapidly directed to action when they asked in a community meeting: "What is relevant science?"

The response was: "We are hungry." If the question had no relevance to the answer, then what was the point of the question? We had imagined that over time we would address issues of community well-being, but improvement of community well-being had to be addressed immediately. As a first requirement of relevance, the community wanted science education to help alleviate poverty. We were being asked not simply to collect answers to our research question, but to respond to them; to participate in the community's agenda as part of their participation in ours. Any model of 'relevant science education' would have to show how it linked to and promoted community development, and this required a development dimension to the research. At the same time, the communities, including the schools, expressed their wishes for deeper levels of participation than we had anticipated. Thus, participation led to major shifts in the scope and purposes of the research, and, recursively, in the depths of participation. (Malcolm et al., 2009, p. 198)

Malcolm et al. (2009) report participative processes led to conceptualisations of relevant science education centred on community development (economic and social), school community collaboration, and project-based learning. Through a series of community meetings and workshops, a project focused on sustainable agriculture, health care, HIV/AIDS, the creation of markets, and the ability to create employment was articulated. Community members were also interested in gaining access to computer skills and the knowledge such information technologies can make available to high-poverty rural communities. The idea of villagers, researchers, teachers and children learning through projects arose by interpreting the stated needs and aspirations and translating them into a design to address those concerns and be culturally congruent. The idea emerged that curriculum development should be embedded in community development, via school-community projects. It was a way of bringing together education and development, school and community, research and action, and accepting the community's observation that relevant science education would surely do something about poverty in the village.

\section{The Meaning of Sustainable Development}

If we were to ask the 'person on the street' the meaning of sustainable development we would likely hear a variety of responses, ranging from the ways in which individuals might contribute to sustainable development to current and emerging 
global issues. The responses might also reflect a range of emotions. This is simply because sustainable development is a complex, multi-faceted concept, which according to Ratcliffe and Grace (2003) combines aspects of environmental protection with social equity and the quality of human life. Indeed, there are as many definitions as there are practitioners in the field, with over 65 definitions of the term in circulation (Symons, 1997). But, the two most commonly quoted definitions are as follows:

Sustainable development (means) improving the quality of human life while living within the carrying capacity of supporting ecosystems. (UNEP / WWF 1991, p. 211)

Sustainable development is development that meets the needs of the present without compromising the ability of future generations to meet their own needs. (WCED, 1987, What is Sustainable Development section, ๆ1)

Sustainable development is therefore essentially about the simultaneous struggle for balance, for harmony between environmental protection and economic development. These definitions are not without their critics. They have been considered somewhat inadequate or out of tune with the process of education, particularly science and technology education (Holbrook, 2009). Be that as it may, it would be worthy to consider the meaning of relevant science education in the context of sustainable development. Thus, the two definitions derived from development principles suggest a relevant science education for sustainable development may be construed as an education that:

...enables people to develop the knowledge, values and skills to participate in decisions about the way we do things individually and collectively both locally and globally that will improve the quality of life now without damaging the planet for the future. (DETR, 1990, p. 30)

One might reasonably ask, "What does this look like in practice?" In a collaborative research project oriented toward social responsibility and sustainability, Sinnes, Kyle and Alant (2010) indicate Project SUSTAIN students seem to have a very clear understanding of what they see as a socially responsible SMT education. According to the students in Project SUSTAIN, a socially responsible SMT education would have to:

$>$ respond to the challenges in the environment where the pupils live;

$>$ empower people and transform their lives;

$>$ be rooted in their cultural context;

$>$ echo the needs of the pupils, be creative, and teach pupils to become creative;

$>$ provide democratic spaces for learning; 
$>$ teach pupils not only to understand, but to act;

$>$ be responsive to the environmental threats and teach individuals to act in a way that does not destroy the environment; and

$>$ teach pupils to act responsibly.

Thus, a relevant science education for sustainable development is that which is intended within the school curriculum to maximize the socio-cultural relevance of science education in helping learners to achieve the goals of sustainable development.

\section{Some Remaining Issues: Socio-scientific Issues and the Curriculum}

Over the past 100 years or so, science has been progressively inserted into the school curriculum. Yet, its original purpose (that of preparing students for University studies) has more or less remained the predominant determinant of the content and pedagogy (Holbrook, 2009). Many science educators (Holbrook, 2009; Kyle, 2006; Ratcliffe \& Grace, 2003) have asserted the science content for learning still carries a strong conceptual tone characterizing science preparation for an elite group. As Kyle (2006) notes, it ignores the wider complex of socio-cultural and political factors that influence the ways schooling is structured for the benefit of some students more than others. Moreover,

when students experience an education in science that is limited to the guiding interests of instrumental reason, they are denied a form of knowledge that enables them to develop and change culture, including the culture of science It is imperative that students have the opportunity to experience the hermeneutic and critical sciences in the context of their formal education in science. The goal of science education should be to facilitate both students' and the public's ability to identify possibilities, to seek challenges, to use their imagination, to transform. Students' experiences with science ought to be self-involving, socially just, and emanicipatory. (Kyle, 2006, pp. $9-10$ )

Scientists have come a long way from the ivory tower and many scientists nowadays are well aware of societal needs and constraints associated with the nature of their inquiry. Research activities have emerged focusing on sustainability sciences and interdisciplinary research groups are working on such issues as health care, sustainable agriculture, food security and food production. However, even though it has become important to demonstrate the value of research, this value is often still expressed in economic terms. How can we incorporate societal issues and a focus upon present-day innovative research agendas in science and technology education? Where in the curriculum should socio-scientific issues be located and how can the curricular support for such teaching be provided? These are some of the challenges as we strive to create opportunities for interdisciplinary learning in the sciences. On March 5-6, 2009, the first in the series of Biennial Conferences on Human Security in 
Africa transpired with a focus upon how agriculture, education and health can be leveraged to enhance human security in Africa. The resulting edited volume offers a valuable first step toward addressing the issues of importance while offering recommendations for policy formulation and implementation (Obasanjo, Mabogunje, \& Okebukola, 2010). Getting the balance right between a sufficient number of students going on to scientific and technological careers and providing all students with enough motivation and knowledge of science and technology to appreciate the importance of those subjects in society is perhaps the major educational issue facing all countries today (Holbrook, 2009).

Clearly we believe the aims of school science need to be examined with respect to sustainable development. We have implied that science education for sustainable development is essentially the province of science teachers and science educators. However, in practice, the situation is not always that obvious. Although consideration of socio-scientific issues involves many facets, some writers have argued (e.g., Dawson, 2000) that given their particular educational background science teachers are not necessarily well equipped to teach about society and social issues. Rather they are better placed to focus more on the features of the scientific enterprise and the strengths and limitations of science. While there may be some considerable sympathy for that view, Ratcliffe and Grace (2003) have suggested that the subject structure of the curriculum could give rise to two extremes:

- Learners consider socio-scientific issues in lessons other than science, essentially for developing skills of reasoning, communicating and analysis, and yet not necessarily appreciating the strengths and limitations of scientific processes and content in addressing the issue. Thus, science lessons can be seen as devoid of social context and unrelated to topical sustainable development issues say.

- Learners consider socio-scientific issues in science lessons, used in developing skills of reasoning, communication and analysis and appreciating the strengths and limitations of scientific processes and content in addressing the particular issue. Thus the demands on the science teacher or educator and the science curriculum become integrated and all-embracing.

Because socio-scientific issues straddle the formal curriculum, the issue of the extent to which socio-scientific issues are the province of science education or humanities education is always a point of debate and discussion. However, given the need for both students and citizens to be able to participate in socio-scientific discourse, the question arises: In what ways should science curriculum be connected to issues associated with sustainable development, particularly in Africa, so as to make science teaching more relevant, meaningful and accessible to learners? 
O'Donoghue (2010), grounding his work in Bhaskar's (1989, 1993, 2008) Critical Realism, searches for a more refined lived world perspective for engaging modern science as a source of object congruent tools to mediate difference by probing cases of situated learning and change. "We have now reached a stage that the conditions of our times are cut through by risk and fear for future sustainability. This is driving a curriculum of fearful alienation and wrath with little chance of redemption because the necessary change is complex, contested and unclear. Critical realism redirects an ontology of intergenerational being in the world, potentially allowing us to reduce the current ontological terror at the heart of problem / issue-centred environment and sustainability education, pointing to a methodological move from taking problems to children to a curriculum of engagement in sustainability practices for the common good O'Donoghue, 2010, p. 63).

Interestingly enough, a consistent message from proponents of cross national science achievement surveys, such as TIMMS, is that science education will be transformed by implementing norms and standards that assess students' technical knowledge and engaging them in such cross-national comparisons of science achievement. Recently, such views have come under criticism and are currently being challenged. For example, Kyle (2006) argues that such international comparisons tend to invoke a narrow image of science by emphasizing more the technical interests of the empirical-analytical sciences at the expense of the practical and emancipatory interests of the hermeneutic-interpretive sciences. Moreover, it neglects the fundamental issues of the place of science in the larger social context and fails to acknowledge the political situatedness of science. In essence, students and citizens alike have been denied access to the social and political process of science. Similarly, O'Donoghue (2010) addresses the situating primacy of cultural practice for meaningful learning with epistemological access in modern curriculum settings. He notes an inadequate sense of the primacy of the mediating cultural preconditions in meaning-making interactions that appear to have produced a pedagogical barrier of cultural exclusion, the reification of concepts ordered in detached hierarchies accompanied by a process reduction in science (empiricism as the scientific method). He asserts the latent exclusion of being in the world has constituted science as a field of detaching exclusivity where expert communities of practice mediate the induction of others. Currently, expert mediation to induct modern African children is failing with scientific abstractions proving of little relevance and the field being inaccessible to all but the elite.

Drawing on the experiences of community activism for sustainable development (e.g., Malcolm et al., 2009; O'Donoghue, 2010), we argue for the introduction of novel pathways that link science education to the goals of sustainable development. If formal education is about eliciting and expanding upon the existing knowledge and life experiences that learners bring to classroom situations, then a universal image of science as opposed to a contextual one of science has to be untenable. Learners come into the science classroom with different background experiences and worldviews. 
Education in science must be contextualized and linked to the life world experiences of the learners, while taking into consideration issues of locality, interest, and cultural values. Thus, engagement with sustainable development issues will only become meaningful when students see the issue as relevant and important. Such an education in science will facilitate the emergence of a far more reflective, relevant and insightful science education provision for sustainable development.

\section{An Agenda for Action}

In order to integrate the goals of sustainable development into science education, there is a need to widen our vision beyond the content and process aims of science teaching and learning, and expand our view of the goals of science education. What is needed is a shift of emphasis of science education from one bound by subject matter headings - from learning science as a body of knowledge to learning science linked to contextual realities of life and living. An important reason for this shift is the apparent isolation of many science curricula that are quite divorced from such a perspective.

Greene (1995) emphatically states the main point of education in the context of a lived life is "to enable a human being to become increasingly mindful with regard to his or her lived situation - and its untapped possibilities" (p. 182). Science is a human activity. The values of science are therefore human values. As Bronowski (1956/65) posits, the strengths of science and its safeguards rest predominantly on principles of freedom, notably, free inquiry, free thought, free speech and tolerance, all of which are the hallmarks of respect of human rights, freedom, and democracy. Learners ought to be afforded the opportunity to exercise such principles in the process of learning science. It is through experiencing such an education in science that they are also able to embed themselves in what is referred to as a "web of human relationships" (Arendt, 1985, p. 183), thus enabling the teacher to integrate issues of sustainable development, free speech and critical discussions into the curriculum.

In reflecting about the appropriate curriculum for relating science education and issues of sustainable development, we are drawn to the publication, Beyond 2000, a Nuffield Seminar Series report that has proved influential in shaping some of the directions of the UK science curriculum. The outcome of Beyond 2000 spells out the aims of the science curriculum, which includes that students should be able to:

- appreciate why the important ideas and explanatory frameworks of science are valued;

- appreciate the underlying rationale for decisions (for example about energy use, or medical treatment or ) which they may wish or be advised, to take in everyday contexts, both now and in later life;

- understand and respond critically to, media reports of issues with a science component; 
- feel empowered to hold and express a personal point of view on issues with a science component which enter the arena of public debate, and perhaps to become actively involved in some of these;

- acquire further knowledge when required either for interest or for vocational purposes. (Millar \& Osborne, 1998)

Such aims resonate with our vision of the very ways in which science education can be connected to issues of sustainable development. They also imply that the teaching approaches should be consistent with giving students opportunities to experience the hermeneutic or interpretative sciences in the context of their formal schooling, in ways that are self-involving, transformative, and emancipatory (cf. Kyle, 2006).

Although researchers and policy makers may not always agree as to the appropriate content in science education for sustainable development, the balance of appropriate curriculum content is dependent upon the perspective of any society's purposes or goals of science education (Law et al., 2000). Tilbury (1995) provides support to this integrative approach of linking the discipline of science education to contextual realities of life and living relevant to the learner. The societal and personal well being priorities have some overlap with science education for sustainable development. With this inclination for relevance, there is an increasing recognition that science education should be fostering engagement with goals of sustainable development in various domains such as health and environment, poverty alleviation and economic prosperity, conservation of nature and erosion eradication, stewardship and civic responsibility (cf. Kyle, 2006).

\section{Conclusion}

In conclusion, for too long science education has been disassociated from the contextual realities of life. This leads us to ask, "Why have science educators not regarded education as a primary means of investing in human resources and for promoting development?" Science education classrooms ought to be permeated by socio-scientific themes, if indeed we wish to prepare future citizens able to deal with complex everyday issues. This is not a modest goal. We must begin to prepare students who will act as informed and responsible citizens when faced with issues related to sustainable development. After all, the goals of sustainable development are premised on a scientifically literate citizenry.

On December 24, 1968, Frank Borman, Jim Lovell and Bill Anders - the three person crew of Apollo 8 - were the first people to orbit the Moon, they were the first people to lose complete contact with their own planet, and on their fourth orbit Commander Frank Borman rolled the aircraft away from the moon to complete a navigational fix and as the windows tilted toward the horizon there was a sudden view of the Earth, rising. They were the first to see the image later to become known 
as "Earthrise." That image of Earth rising in the vast darkness of space over the landscape of the Moon has offered inspiration to everyone who has seen the picture for over 40 years now. Seeing our home from space, realizing it is the only home we have, and that we had better care for our planet offers the inspiration to do so. The image from space spawned environmental movements and awakened a public consciousness with respect to the fragility of a planet that seems so immense to the residents who live there, but so small when viewed from the close proximity of its natural satellite.

McKibben (2010) aptly declares, "But we no longer live on that planet" (p. 2). He notes that in the four decades since that magnificent picture, Earth has changed in profound ways. He asserts "we imagine we still live back on that old planet, that the disturbances we see around us are the old random and freakish kind. But they're not. It's a different place. A different planet. It needs a new name. Eaarth" (p. 2). Are we ready to take up the challenges of this new planet? In the process, science educators must contribute in meaningful ways to creating the infrastructure for the world that comes next. After all, that is what educating for sustainable development is really all about.

\section{References}

Anderson, I. K. (2006). The relevance of science education as seen by pupils in Ghanaian junior secondary schools. A Thesis submitted in partial fulfilment of the requirements of the degree of Doctor of Philosophy. University of the Western Cape, South Africa (http://www.ils.uio.no/english/rose/network/countries/uk-england/ukengland.html).

Annan, K. A. (2002). Foreword. In C. Flavin, H. French \& G. Gardner (Eds.), State of the world 2002 (pp. xvii - xviii). New York: Norton.

Arendt, H. (1958). The human condition. Chicago: University of Chicago Press.

Barton, A. C., \& Osborne, M. D. (Eds.). (2001). Teaching science in diverse settings: Marginalized discourses and classroom practice. New York: Peter Lang.

Bhaskar, R. (1989). Reclaiming reality: A critical introduction to contemporary philosophy. London: Verso.

Bhaskar, R. (1993). Dialectic: The pulse of freedom. London: Verso.

Bhaskar, R. (2008). A realist theory of science. London: Routledge.

Bowers, C.A. (2001). Educating for eco-justice and community. Athens, GA: University of Georgia Press.

Bronowski, J. (1956/1965). Science and human values (Rev. ed.). New York: Harper \& Row. 
Increasing the Socio-Cultural Relevance of Science Education for Sustainable Development

Brown, L. R. (2008). Plan B 3.0: Mobilizing to save civilization. New York: W. W. Norton.

Caldin, E. F. (1949). The power and limits of science: A philosophical study. London: Chapman \& Hall.

Cheek, D. W. (1992). Thinking constructively about science, technology and society education. Albany, NY: SUNY Press.

Davies, I. (2004). Science and citizenship education. International Journal of Science Education, 26, 1751 - 1763.

Dawson, C. (2000). Selling snake oil: Must science educators continue to promise what they can't deliver? Melbourne Studies in Education, 21(7), 121 - 132.

Department of Education, Pretoria, South Africa. (2002). Revised national curriculum statement for grades $R-9$ schools: Natural sciences. Pretoria, South Africa: Department of Education.

Department of the Environment, Transport and the Regions (DETR). (1999). Sustainable Development Education Panel: First Annual Report 1998. Norwich: The Stationery Office, UK.

European Commission (EUR22845). (2007). Science Education NOW: A renewed pedagogy for the future of Europe. Retrieved January 13, 2010 from http://www.ec.europa.eu/research/science-society/document_library/pdf_06/reportrocard-on-science-education_en.pdf.

Ewing B., Goldfinger, S., Wackernagel, M., Stechbart, M., Rizk., S. M., Reed, A., \& Kitzes, J. (2008). The Ecological Footprint Atlas 2008. Oakland, CA: Global Footprint Network.

Fien, J. (1993). Environmental education: A pathway to sustainability? Geelong, Australia: Deakin University Press.

Finger, J.M., \& Schuler, P. (2004). Poor people's knowledge: Promoting intellectual property in developing countries. Washington, DC: World Bank.

Gee. J. P. (2005). An introduction to discourse analysis: Theory and method $\left(2^{\text {nd }}\right.$ ed.). New York: Routledge.

Glenn, J. C., Gordon, T. J., \& Florescu, E. (2009). 2009 State of the Future. Washington, DC: The Millennium Project.

Glenn, J. C., Gordon, T. J., \& Florescu, E. (2011). 2011 State of the Future. Washington, DC: The Millennium Project. 
Global Footprint Network. (2010, March 18). Earth overshoot day 2009. Retrieved April 24, 2010, from http://www.footprintnetwork.org/en/index.php/GFN/page/earth overshoot_day/\#WOD.

Greene, M. (1995). Releasing the imagination: Essays on education, the arts, and social change. San Francisco: Jossey-Bass.

Habermas, J. (1972). Knowledge and human interests. (J. J. Shapiro, trans.). London: Heinemann (original work published in 1968).

Heater, D. (1999). What is Citizenship? Cambridge: Polity Press

Hodson, D. (2003). Time for action: Science education for an alternative future. International Journal of Science Education, 25, 645 - 670.

Holbrook, J. (2009). Meeting challenges to sustainable development in Africa through science and technology education: Conference Concept Paper. Abuja, Nigeria: ICASE African Regional Office.

International Council of Associations for Science Education (ICASE). (2003). Increasing the relevance of science and technology education for all for the $21^{\text {st }}$ century: Framework Document. Retrieved January 10, 2010 from http://www.icaseonline.net/the.html.

Jenkins, E. W. (2006). The student voice and school science education. Studies in Science Education, 42, 49 - 88.

Jenkins, E. W., \& Pell, R. G. (2006). The Relevance of Science Education Project (ROSE) in England: A summary of findings: Centre for Studies in Science and Mathematics Education, University of Leeds. Available at: http://www.ils.uio.no/english/rose/net work/countries/uk-england.html.

Kyle, W. C., Jr. (1999). Science education in developing countries: Access, equity, and ethical responsibility. Journal of the Southern Africa Association for Research in Mathematics and Science Education, 3, 1 - 13.

Kyle, W. C., Jr., (2002). Critical issues of school and teacher education reform: Transforming science teaching and learning for a new millennium. In P.A. Chakalisa, C. D. Yandilla, H. U. Emerole, I. J. Kyeleve, G. J. Ramogoro, \& A.A. Babugara (Eds.) Science, technology, and mathematics education in Africa (pp xvi-xxxi, xxxv). Gaborone, Botswana: University of Botswana.

Kyle, W.C. Jr. (2006). The Road from Rio to Johannesburg: Where are the footpaths to / from Science Education? International Journal of Science and Mathematics Education, 4, $1-18$. 
Increasing the Socio-Cultural Relevance of Science Education for Sustainable Development

Law, N., Fensham, P., Li, S., \& Wei, B. (2000). Public understanding of science as basic literacy. Melbourne Studies in Education, 41 (2), 145 - 55, Special Issue: Science and the Citizen.

Malcolm, C., Gopal, N., Keane, M., Kyle, W. C., Jr. (2009). Transformative action research: Issues and dilemmas in working with two rural South African communities. In K. Setati, R. Vithal, C. Malcolm, \& R. Dhunpath (Eds.), Researching possibilities in mathematics, science and technology education (pp. 193 - 212). New York: Nova Science Publishers.

McKibben, B. (2010). Eaarth: Making a life on a tough new planet. New York: Times Books.

Millar, R., \& Osborne, J. (Eds.). (1998). Beyond 2000: Science education for the future. London: King's College.

National Research Foundation Report (NRF). (2005). Key Performance Indicator Report 2004/2005. Available at:http://www.nrf.ac.za/publications/annrep/ annualreport04 _05.pdf.

Obasanjo, O., Mabogunje, A., \& Okebukola, P. (Eds.). (2010). Human security in Africa: Perspectives on education, health and agriculture. Abeokuta, Nigeria: The Center for Human Security, Olusegun Obasanjo Presidential Library.

O'Donoghue, R. (2010, January). Science, mathematics and technology education research unlocking barriers across lived world and expert mediated frontiers of learning for a sustainable future. Proceedings of the $18^{\text {th }}$ Annual Meeting of the Southern African Association for Research in Mathematics, Science and Technology Education, Durban, South Africa, pp. 57-69.

Onwu, G. O. (2000). How should we educate science teachers for a changing society? South African Journal of Higher Education, 14 (3), 43 - 50.

Onwu, G. O., \& Mogari, D. (2004). A model of professional development for outcomes based education science curriculum implementation: the Case of UNIVEMALASHI South Africa. Journal of Education in Teaching: International Research and Pedagogy, 30, $161-177$.

Ratcliffe, M., \& Grace, M. (2003). Science education for citizenship. Maidenhead: Open University Press

Roberts, D. A. (1982). Developing the concept of "curriculum emphasis" in science education. Science Education, 66, 243 - 260.

Roberts, D. A. (1988). What counts as science education? In P. Fensham (Ed.), Development and dilemmas in science education (pp. 27 - 54). Philadelphia: Falmer Press. 
Roberts, D. A. (2007). Scientific literacy / science literacy. In S. K. Abell \& N. G. Lederman (Eds.), Handbook of research on science education (pp. 729 - 780). New York: Routledge.

Roth, W.-M. (2007). Toward a dialectical notion and praxis of scientific literacy. Journal of Curriculum Studies, 35, 9 - 24.

Roth, W.-M., \& Desautels, J. (Eds.). (2002). Science education as / for sociopolitical action. New York: Peter Lang.

Roth, W.-M., \& Lee, S. (2004). Science education as / for participation in the community. Science Education, 88, 263 - 291.

Sadler, T. D. (2009). Situated learning in science education: Socio-scientific issues as contexts for practice. Studies in Science Education, 45, 1 - 42.

Schayegh, C. (2007). The social relevance of knowledge: Science and the formation of modern Iran, 1910s - 1940s. Middle Eastern Studies, 43, 941 - 960.

Schreiner, C., \& Sjøberg, S. (2004). Sowing the seeds of ROSE (The Relevance of Science Education): Background, rationale, questionnaire development and data collection for ROSE - A comparative study of students' views of science and science education (pdf) (Acta Didactica 4/2004). Oslo: Dept. of Teacher Education and School Development, University of Oslo. Available at: http://www.ils.uio.no/english/rose/.html.

Sinnes, A. T., Kyle, W. C., Jr., \& Alant, B. P. (2010, January). What is socially responsible science education? Perspectives from students in Project SUSTAIN. Proceedings of the $18^{\text {th }}$ Annual Meeting of the Southern African Association for Research in Mathematics, Science and Technology Education, Durban, South Africa, pp. 101 108.

Solomon, J., \& Aikenhead, G. (1994). STS education: International perspectives on reform. New York: Teachers College Press.

Stears, M., Malcolm, C., \& Kowlas, L. (2003). Making use of everyday knowledge in the science classroom. African Journal of Research in Science, Mathematics and Technology Education, 7, 109-118.

Stevenson, R. B., \& Dillon, J. (Eds.). (2010). Engaging environmental education: Learning, culture and agency. Rotterdam, The Netherlands: Sense Publishers.

Symons, G. (1997). Sustainability in action in Britain? Godalming, UK: World Wilde Fund.

Tilbury, D. (1995). Environmental education for sustainability: Defining the new focus of environmental education in the 1990s. Environmental Education Research, 1 (2), 195-212. 
Increasing the Socio-Cultural Relevance of Science Education for Sustainable Development

Tobin, K. (2009). Research priorities for transforming urban science education. In W.-M. Roth \& K. Tobin, The World of Science Education: Handbook of Research in North America, pp. 451 - 471. Rotterdam, The Netherlands: Sense Publishers.

United Nations Commission on Sustainable Development (2002). The Johannesburg summit test: What will change? Available at www.johannesburgsummit.org.

UNEP (United Nations Environment Programme) / WWF (World Wide Fund for Nature). (1991). Caring for the Earth: A strategy for sustainable living. Gland, Switzerland: IUCN - The World Conservation Union UNEP - United Nations Environment Programme WWF-World Wide Fund for Nature.

UNEP (United Nations Environment Programme). (1995). Global diversity assessment. Cambridge: Cambridge University Press.

UNICEF. (2003). State of the world's children 2003. New York: UNICEF. Available at www.unicef.org.

van Eijck, M. (2009). Scientific literacy: Past research, present conceptions, and future developments. In W.-M. Roth \& K. Tobin (Eds.), Handbook of Research in North America (pp. 245 - 258). Rotterdam, The Netherlands: Sense Publishers.

Wackernagel, M. (2008). Forward. In B. Ewing, S. Goldfinger, M. Wackernagel, M. Stechbart, S. M. Rizk, A. Reed, \& J. Kitzes, J. The Ecological Footprint Atlas 2008 (pp. 1-2). Oakland, CA: Global Footprint Network.

WCED (World Commission on Environment and Development). (December 11, 1987). Our common future. Oxford: Oxford University Press. Retrieved from: http://habitat.igc.org/open-gates/wced-ocf.htm, What is Sustainable Development section, $\llbracket 1$ ).

World Bank. (2003). World Development Report 2003: Sustainable development in a dynamic world. New York: Oxford University Press.

World Bank. (2004a). World Development Report 2004: Making services work for poor people. New York: Oxford University Press

World Bank. (2004b). 2004 World Development Indicators. Washington DC: World Bank.

World Bank. (2004c) African Development Indicators 2004. Washington, DC: World Bank.

Ziman, J. (2000). Real science: What it is, and what it means. New York: Cambridge University Press. 